УДК 637.7

DOI https://doi.org/10.32838/TNU-2663-5941/2020.6-2/17

Скульська I.В.

Львівський національний університет ветеринарної медицини та біотехнологій імені С.3. Гжицького

\title{
Цісарик О.Й.
}

Львівський національний університет ветеринарної медицини та біотехнологій імені С.3. Гжицького

Сливка Н.Б.

Львівський національний університет ветеринарної медицини та біотехнологій імені С.3. Гжицького

\section{ФОРМУВАННЯ ЯКІСНИХ ПОКАЗНИКІВ БРИНЗИ, ВИГОТОВЛЕНОЇ ЗА ЧАСТКОВОЇ ЗАМІНИ ХЛОРИДУ НАТРІЮ}

У статті досліджено основні органолептичні та фізико-хімічні показники розсільного сиру бринзи, яка виготовлена з овечого молока за удосконаленою технологією. Встановлено основні технологічні рімення для забезпечення підвищення якісних показників сиру завдяки можливості удосконалення деяких технологічних операщій, а саме операції соління шляхом зниження вмісту кухонної солі у бринзі за рахунок часткової ї̈ заміни хлоридом калію.

У результаті проведених досліджень встановлено максимальний відсоток заміни кухонної солі хлоридом калію, який становить 30\%. Зразки бринзи із 50 і 100\% заміною характеризувалися гірким присмаком $і$ йодистим запахом і присмаком. Таким чином, удосконалення технології полягає у 20 і 30\% заміні кухонної солі хлоридом калію. Завдяки иьому вміст кухонної солі знижується до мінімального значення, яке передбачене діючою нормативною документацією (4\%). У дослідних зразках вміст кухонної солі на 0,82-0,97\% менший. Це забезпечуе зниження споживання кухонної солі при добовій нормі спожсивання сиру (70 2). Загалом було виготовлено 3 зразки сиру бринза із частковою заміною кухонної солі хлоридом калію: $K$ - контрольний зразок із використанням хлориду натрію; Д1 і Д2 - бринза, виготовлена із 20 і 30\% заміною хлориду натрію хлоридом калію.

За результатами проведених досліджень органолептичні та фізико-хімічні показники бринзи, яка виготовлена за удосконаленою технологією, повністю відповідають вимогам нормативної документачії: смак у міру солоний; запах чистий, кисломолочний, властивий овечому молоку; консистенція пружна, ламка, але не крихка; колір - білий, злегка з кремовим відтінком; кірка відсутня. У дослідних зразках бринзи спостерігається підвищення вмісту сухих речовин, що збільшує вихід сиру. Оскільки бринза містить мінімально допустимий вміст солі (4\%), то рекомендується вживати ї̈ як компонент для безлічі страв людям різних вікових категорій.

Ключові слова: розсільний сир, бринза, кухонна сіль (хлорид натрію), хлорид калію, розсіл, бактеріальний препарат, соління, дозрівання, зберігання.

Постановка проблеми. У світі спостерігається стабільне зростання рівня споживання сирів, що стимулює збільшення обсягів їх виробництва. Виробництво сирів в Україні перевищує обсяги споживання на внутрішньому ринку [1, с. 14-17], що створює умови для їх експорту. Однак вихід на світові ринки вимагає істотного покращення якості сирів [2], створення нових видів та інноваційних технологій і наукового їх обгрунтування.

Натуральні сири $є$ особливо важливими для забезпечення людини повноцінним харчуванням. Вони мають високу біологічну цінність, що зумовлена концентруванням і модифікацією компонентів молока. Сири наділені широкою гаммою смакових відтінків, а їх виробництво відрізняється високою рентабельністю і зрос- танням річних обсягів [3, с. $24-27$; 4, с. 327 ; 5 , с. $17-19 ; 6$, c. 14$]$.

Останнім часом спостерігається збільшення зацікавленості споживачів розсільними сирами. До розсільних сирів традиційного асортименту належать чанах, тушинський, осетинський, кобійський, єреванський, грузинський, сулугуні, бринза, моцарелла, чечіл і місцеві (національні болгарський сирене, турецький беяз пейнір, румунська й українська бринза; іранський лігван, ліванський набульсі) види. Виготовляються розсільні сири у багатьох країнах Європи - Німеччині, Греції, Румунії, Болгарії, Франції. Масове виробництво розсільного сиру є найпоширенішим у Нідерландах та Греції. Асортимент розсільних сирів складається 3 понад 30 найменувань. 
В Україні традиційним способом виготовляється бринза із овечого молока.

Аналіз останніх досліджень i публікацій. Великий внесок у розвиток теоретичних i практичних основ виробництва розсільних сирів здійснили закордонні та вітчизняні вчені Г.Б. Рудавська, 3.Х. Диланян, В.М. Туринський, P.F. Fox, Katsiari, M.S. Vicente, T. Bintsis, P.Papademus, A.A. Hayaloğlu, M. Guven, E.C. Pappa, M.M. Ayyash, F. Sherkat, N.P. Shah.

Особливістю технології розсільних сирів $€$ визрівання у розчині солі певної концентрації. Фізико-хімічні, біохімічні та мікробіологічні процеси в сирі та інтенсивність їх перебігу залежать від концентрації кухонної солі у розсолі. Хлорид натрію посилює гідролітичну здатність сичужного ферменту під час визрівання сиру, гальмує життєдіяльність гнильних бактерій у сирі, при цьому у певних концентраціях сприяє розвитку молочнокислої мікрофлори заквашувальних препаратів і продукуванню нею ферментів. Помірна кількість солі підвищує ступінь гідратації білків сиру, впливаючи на формування пластичної його консистенції, запобігаючи небажаним перетворенням сірковмісних амінокислот, що спричиняє утворення сірководню. Однак надмірне споживання кухонної солі та пов'язані з цим ризики захворювань викликають тривогу та зумовлюють необхідність зниження вмісту кухонної солі $(\mathrm{NaCl})$ у харчових продуктах [7, с. 126].

Одним зі шляхів зменшення концентрації хлориду натрію і попередження погіршення якості бринзи, зменшення термінів іiі зберігання є часткова його заміна хлоридом калію. Про позитивні результати такої заміни засвідчують дані авторів Австралії та США: Ayyash, Sherkat, Shah (2012), Shakeel-Ur-Rehman (2003), Parademas i Robinson (2009). Дослідження проводилися на твердих сирах, проте саме розсільні сири характеризуються найвищим вмістом хлориду натрію (4-7\%), а літературні дані щодо вивчення такої заміни у них відсутні.

Постановка завдання. Актуальність проведення наукових досліджень зумовлена відносно великими обсягами виробництва та споживання бринзи в Україні та необхідністю зниження вмісту кухонної солі у щоденних раціонах, що і стало нашим основним завданням.

Виклад основного матеріалу дослідження. Для виготовлення бринзи з овечого молока було використано ферментний препарат CHY-MAX виробництва фірми Chr. Hansen (Данія). CHYMAX - це рекомбінантний хімозин, отриманий ферментацією за допомогою Aspergillus niger var. Awamori. Він не містить ензимів, здатних розщеплювати крохмаль. Препарат містить молокозсідальні ензими з високою специфічною дією розщеплення æ-казеїну, що в результаті забезпечує дуже добре утворення згустку. Як заквашувальну культуру використано препарат прямого внесення RSF-742 (Chr. Hansen, Данія), який містить у своєму складі такі штами молочнокислих бактерій: Lactococcus lactis subsp. cremoris, Lactococcus lactis subsp. lactis, Streptococcus thermophilus, Lactobacillus helveticus.

Молоко приймали згідно вимог ТУ 10.16 УССР 71-89 «Молоко овечье. Требования при закупках». Відбір проб молока до аналізів проводили згідно ДСТУ ISO 707-2002 (ISO 707:1997, IDT) «Молоко та молочні продукти. Настанови з відбирання проб».

У таблиці 1 наведено органолептичну характеристику бринзи, при виробництві якої використали різний відсоток заміни хлориду натрію хлоридом калію. Заміна хлориду натрію хлоридом калію в кількості 20 і 30\% не призвела до погіршення органолептичних властивостей бринзи, тоді як сир із заміною 50 і 100\% мав характерний йодистий присмак і запах.

Результати балової оцінки якості бринзи наведено у таблиці 2. Якість пакування та маркування, яка складає 5 балів, ми не оцінювали. Отримані результати свідчать, що за смаком, запахом і консистенцією бринза із $20 \%$ і $30 \%$ заміною хлориду натрію хлоридом калію характеризувалася вищою кількістю балів, мала кращий зовнішній вигляд завдяки одноріднішій консистенції, тому у подальших дослідженнях ми використовували 20 і 30\% заміну хлориду натрію хлоридом калію.

Було виготовлено 3 зразки овечого сиру бринза, в якому 20 і 30\% хлориду натрію було замінено на хлорид калію: К - контрольний зразок із використанням хлориду натрію; Д1 і Д2 - бринза, виготовлена із 20 і $30 \%$ заміною хлориду натрію хлоридом калію.

У таблиці 3 наведено органолептичні показники бринзи з овечого молока за 20\% і $30 \%$ заміни хлориду натрію хлоридом калію. За результатами балової оцінки найбільшу кількість балів отримали зразки із частковою заміною кухонної солі хлоридом калію. Бринзу можна віднести до сиру високої якості (таблиця 4). Отже, заміна кухонної солі забезпечує високу якість продукту і відповідність його вимогам нормативної документації [8, c. 12].

У таблицях 5-6 показано зміни фізико-хімічних показників бринзи протягом періоду визрі- 
вання. Звертаємо увагу на зміну активної кислотності: зразки з використанням хлориду калію характеризуються нижчою кислотністю сирного тіста, ніж контрольний зразок. До того ж масова частка вологи зменшується до кінця визрівання у всіх дослідних зразках сиру. Найвищим вмістом вологи $(53,1 \%)$ характеризується контрольний зразок наприкінці визрівання, а найнижчим - зразок із 20\% заміною хлориду натрію хлоридом калію.

Оцінюючи масову частку жиру, бачимо збільшення цього показника до кінця визрівання, що узгоджується зі зростанням масової частки сухих речовин. Аналізуючи вміст солі у сирі, варто зауважити, що його значення підвищується протя- гом усього терміну визрівання. Закономірно, що найвищий вміст $\mathrm{NaCl}$ у зрілій бринзі наявний у контрольних зразках, у дослідних зразках він на 0,82-0,97\% менший. Це забезпечує зниження споживання кухонної солі при добовій нормі споживання сиру (70 г) $[9, \quad$ с. 4747-4759].

Ферменти бактеріальних препаратів і мікробіальних культур відіграють важливу роль у гідролізі білків, утворенні низькомолекулярних пептидів і амінокислот, які слугують попередниками формування смакової композиції сирів та їх біологічної цінності [10, с. 78-88; 11, с. 877-903]. Процеси розщеплення білків і перетворення амінокислот можуть відбуватися як неконтрольовано в сирому незбираному і знежиреному молоці та

Органолептичні показники бринзи

Таблиця 1

\begin{tabular}{|c|c|}
\hline Показник & Характеристика показника \\
\hline \multicolumn{2}{|c|}{ Бринза, соління якої відбувалося у розсолі з кониентрацією хлориду натрію 18\% } \\
\hline Смак і запах & Чистий кисломолочний, у міру солоний, без сторонніх присмаків і запахів \\
\hline Консистенція & Однорідна, ламка, але не крихка \\
\hline Рисунок & 3 поодинокими вічками неправильної форми \\
\hline Колір сирного тіста & Слабо-жовтий, однорідний за всією масою \\
\hline Зовнішній вигляд & $\begin{array}{c}\text { Поверхня чиста, з відбитками серп’янки. Кірка відсутня. } \\
\text { Незначна деформація головки }\end{array}$ \\
\hline \multicolumn{2}{|c|}{ Бринза, соління якої відбувалося у розсолі із 20\% заміною хлориду натрію хлоридом калію } \\
\hline Смак і запах & Чистий кисломолочний, у міру солоний, без сторонніх присмаків і запахів \\
\hline Консистенція & Однорідна, ламка, але не крихка \\
\hline Рисунок & 3 поодинокими вічками неправильної форми \\
\hline Колір сирного тіста & Слабо-жовтий, однорідний за всією масою \\
\hline Зовнішній вигляд & $\begin{array}{c}\text { Поверхня чиста, з відбитками серп’янки. Кірка відсутня. } \\
\text { Незначна деформація головки }\end{array}$ \\
\hline \multicolumn{2}{|c|}{ Бринза, соління якої відбувалося у розсолі із 30\% заміною хлориду натрію хлоридом калію } \\
\hline Смак і запах & Чистий кисломолочний, у міру солоний, без сторонніх присмаків і запахів \\
\hline Консистенція & Однорідна, ламка, але не крихка \\
\hline Рисунок & 3 поодинокими вічками неправильної форми \\
\hline Колір сирного тіста & Слабо-жовтий, однорідний за всією масою \\
\hline Зовнішній вигляд & $\begin{array}{c}\text { Поверхня чиста, з відбитками серп’янки. Кірка відсутня. } \\
\text { Незначна деформація головки }\end{array}$ \\
\hline \multicolumn{2}{|c|}{$\begin{array}{c}\text { Бринза, соління якої відбувалося у розсолі із 50\% заміною хлориду натрію } \\
\text { хлоридом калію }\end{array}$} \\
\hline Смак і запах & Кисломолочний, солоний, з легким запахом і гірким присмаком \\
\hline Консистенція & Однорідна, крихка \\
\hline Рисунок & 3 поодинокими вічками неправильної форми \\
\hline Колір сирного тіста & Слабо-жовтий, однорідний за всією масою \\
\hline Зовнішній вигляд & $\begin{array}{c}\text { Поверхня чиста, з відбитками серп’янки. Кірка відсутня. } \\
\text { Значна деформація головки }\end{array}$ \\
\hline \multicolumn{2}{|c|}{ Бринза, соління якої відбувалося у розсолі з концеентрацією хлориду калію 18\% } \\
\hline Смак і запах & Кисломолочний, дуже солоний, з гірким присмаком \\
\hline Консистенція & Однорідна, крихка \\
\hline Рисунок & 3 поодинокими вічками неправильної форми \\
\hline Колір сирного тіста & Слабо-жовтий, однорідний за всією масою \\
\hline Зовнішній вигляд & $\begin{array}{c}\text { Поверхня чиста, з відбитками серп’янки. Кірка відсутня. } \\
\text { Значна деформація головки }\end{array}$ \\
\hline
\end{tabular}


вторинних продуктах, так і контрольовано у сирній масі під час визрівання сирів, де відбувається найглибший гідроліз білків під дією молокозсідальних ферментів і протеолітичних ферментів заквашувальної мікрофлори. Вміст нітрогеновмісних сполук бринзи протягом визрівання наведено у таблицях 7-8. Спостерігається тенденція до збільшення вмісту загального та загального розчинного Нітрогену у зразках із 20 і $30 \%$ заміною $\mathrm{NaCl}$ на $\mathrm{KCl}$ порівняно з відповідним контролем на 12 добу визрівання.

У зрілій бринзі найвищий вміст загального розчинного Нітрогену зареєстровано для зразка Д1 (30,02 мг/г), найнижчим показником характеризувався контрольний зразок $(28,50$ мг/г). Таким чином, часткова заміна іонів натрію на іони калію та використання відповідних культур впливає на протеолітичні процеси [12, с. 40-45].

Таблиця 2

Балова оцінка бринзи

\begin{tabular}{|c|c|c|c|c|c|c|}
\hline \multirow{2}{*}{ Показник } & \multirow{2}{*}{ Максимальна кількість балів } & \multicolumn{5}{|c|}{ Зразки бринзи з відповідним відсотком заміни } \\
\cline { 3 - 7 } & & контроль & $\mathbf{2 0}$ & $\mathbf{3 0}$ & $\mathbf{5 0}$ & $\mathbf{1 0 0}$ \\
\hline Смак і запах & 45 & 42 & 43 & 43 & 17 & 5 \\
\hline Консистенція & 25 & 22 & 22 & 23 & 21 & 19 \\
\hline Рисунок & 10 & 8 & 8 & 8 & 7 & 7 \\
\hline $\begin{array}{c}\text { Колір } \\
\text { сирного тіста }\end{array}$ & 5 & 5 & 5 & 5 & 5 & 5 \\
\hline $\begin{array}{c}\text { Зовнішній } \\
\text { вигляд }\end{array}$ & 10 & 8 & 7 & 8 & 6 & 6 \\
\hline Сума балів & 95 & 85 & 85 & 87 & 56 & 42 \\
\hline
\end{tabular}

Органолептичні показники бринзи з овечого молока

Таблиця 3 за часткової заміни хлориду натрію хлоридом калію

\begin{tabular}{|c|c|c|c|c|c|}
\hline Зразок & Смак і запах & Консистенція & Рисунок & Колір & $\begin{array}{c}\text { Зовнішній } \\
\text { вигляд }\end{array}$ \\
\hline K & $\begin{array}{c}\text { Чистий } \\
\text { кисломолочний, } \\
\text { у міру солоний, } \\
\text { без сторонніх } \\
\text { присмаків і запахів }\end{array}$ & $\begin{array}{l}\text { Однорідна, ламка, } \\
\text { але не крихка }\end{array}$ & $\begin{array}{c}3 \text { поодинокими } \\
\text { вічками } \\
\text { неправильної } \\
\text { форми }\end{array}$ & $\begin{array}{c}\text { Слабо-жовтий, } \\
\text { однорідний за } \\
\text { всією масою }\end{array}$ & $\begin{array}{c}\text { Поверхня чиста, } \\
\text { з відбитками } \\
\text { серветки. Кірка } \\
\text { відсутня }\end{array}$ \\
\hline Д1 & $\begin{array}{c}\text { Чистий } \\
\text { кисломолочний, } \\
\text { у міру солоний, } \\
\text { без сторонніх } \\
\text { присмаків і запахів }\end{array}$ & $\begin{array}{c}\text { Однорідна, ламка, } \\
\text { але не крихка }\end{array}$ & $\begin{array}{c}3 \text { поодинокими } \\
\text { вічками } \\
\text { неправильної } \\
\text { форми }\end{array}$ & $\begin{array}{c}\text { Слабо-жовтий, } \\
\text { однорідний за } \\
\text { всією } \\
\text { масою }\end{array}$ & $\begin{array}{c}\text { Поверхня чиста, } \\
\text { з відбитками } \\
\text { серветки. Кірка } \\
\text { відсутня. Незначна } \\
\text { деформація головки }\end{array}$ \\
\hline Д2 & $\begin{array}{c}\text { Чистий } \\
\text { кисломолочний, } \\
\text { у міру солоний, } \\
\text { без сторонніх } \\
\text { присмаків і запахів }\end{array}$ & $\begin{array}{c}\text { Однорідна, ламка, } \\
\text { але не крихка }\end{array}$ & $\begin{array}{c}3 \text { поодинокими } \\
\text { вічками непра- } \\
\text { вильної } \\
\text { форми }\end{array}$ & $\begin{array}{c}\text { Слабо-жовтий, } \\
\text { однорідний за } \\
\text { всією } \\
\text { масою }\end{array}$ & $\begin{array}{c}\text { Поверхня чиста, } \\
\text { з відбитками } \\
\text { серветки. Кірка } \\
\text { відсутня. Незначна } \\
\text { деформація головки }\end{array}$ \\
\hline
\end{tabular}

Балова оцінка бринзи з овечого молока

\begin{tabular}{|c|c|c|c|c|}
\hline \multirow{2}{*}{ Показник } & \multirow{2}{*}{$\begin{array}{c}\text { Максимальна } \\
\text { кількість балів }\end{array}$} & $\mathbf{K}$ & Зразки бринзи \\
\cline { 3 - 5 } & 45 & 43 & 43 & 22 \\
\hline Смак і запах & 25 & 22 & 22 & 23 \\
\hline Консистенція & 10 & 8 & 5 & 8 \\
\hline Рисунок & 5 & 5 & 7 & 5 \\
\hline Колір сирного тіста & 10 & 7 & 85 & 8 \\
\hline Зовнішній вигляд & 95 & 85 & & 87 \\
\hline Сума балів & & & & \\
\hline
\end{tabular}


Таблиця 5

Фізико-хімічні показники бринзи з овечого молока за часткової заміни хлориду натрію хлоридом калію на 10 добу визрівання

\begin{tabular}{|c|c|c|c|c|c|}
\hline \multirow{2}{*}{$\begin{array}{c}\text { Зразки } \\
\text { бринзи }\end{array}$} & $\begin{array}{c}\text { Масова частка жиру } \\
\text { в сухій речовині, \% }\end{array}$ & $\begin{array}{c}\text { Масова частка } \\
\text { вологи, \% }\end{array}$ & $\begin{array}{c}\text { Масова частка } \\
\text { NaCl + КCl, \% }\end{array}$ & $\begin{array}{c}\text { Масова частка } \\
\text { NaCl, \% }\end{array}$ & $\begin{array}{c}\text { Активна } \\
\text { кислотність, } \\
\text { одиниць, рН }\end{array}$ \\
\hline К & $42,0 \pm 0,3$ & $66,0 \pm 0,2$ & $4,10 \pm 0,1$ & $4,10 \pm 0,1$ & $4,30 \pm 0,03$ \\
\hline Д1 & $41,0 \pm 0,3$ & $64,8 \pm 0,3$ & $4,25 \pm 0,2$ & $3,40 \pm 0,2$ & $4,27 \pm 0,02$ \\
\hline Д2 & $42,0 \pm 0,2$ & $63,2 \pm 0,3$ & $4,08 \pm 0,1$ & $3,26 \pm 0,1$ & $4,31 \pm 0,03$ \\
\hline
\end{tabular}

$(\mathrm{n}=3, \mathrm{p}<0,05)$

Таблиця 6

Фізико-хімічні показники бринзи з овечого молока за часткової заміни хлориду натрію хлоридом калію на 20 добу визрівання (зрілий сир)

\begin{tabular}{|c|c|c|c|c|c|}
\hline \multirow{2}{*}{$\begin{array}{c}\text { Зразки } \\
\text { оринзи }\end{array}$} & $\begin{array}{c}\text { Масова частка жиру в } \\
\text { сухій речовині, \% }\end{array}$ & $\begin{array}{c}\text { Масова частка } \\
\text { вологи, \% }\end{array}$ & $\begin{array}{c}\text { Масова частка } \\
\text { NaCl + КСl, \% }\end{array}$ & $\begin{array}{c}\text { Масова частка } \\
\text { NaCl, \% }\end{array}$ & $\begin{array}{c}\text { Активна } \\
\text { кислотність, } \\
\text { одиниць, рН }\end{array}$ \\
\hline К & $45,9 \pm 0,3$ & $53,1 \pm 0,2$ & $4,2 \pm 0,1$ & $4,2 \pm 0,1$ & $4,23 \pm 0,03$ \\
\hline Д1 & $44,3 \pm 0,3$ & $52,2 \pm 0,3$ & $4,3 \pm 0,2$ & $3,44 \pm 0,2$ & $4,22 \pm 0,02$ \\
\hline Д2 & $45,8 \pm 0,2$ & $52,4 \pm 0,3$ & $4,1 \pm 0,1$ & $3,28 \pm 0,1$ & $4,33 \pm 0,03$ \\
\hline
\end{tabular}

$(\mathrm{n}=3, \mathrm{p}<0,05)$

Таблиця 7

Нітрогеновмісні сполуки бринзи на 12 добу визрівання

\begin{tabular}{|c|c|c|c|c|}
\hline $\begin{array}{c}\text { Зразки } \\
\text { бринзи }\end{array}$ & $\begin{array}{c}\text { Загальний } \\
\text { Нітроген, мг/г }\end{array}$ & $\begin{array}{c}\text { Загальний } \\
\text { розчинний } \\
\text { Нітроген, мг/г }\end{array}$ & $\begin{array}{c}\text { Нітроген небілкових розчинних } \\
\text { нітрогеновмісних сполук, мг/г }\end{array}$ & $\begin{array}{c}\text { Нітроген розчинних } \\
\text { білкових речовин, мг/г }\end{array}$ \\
\hline К & $28,80 \pm 0,12$ & $14,96 \pm 0,12$ & $2,32 \pm 0,12$ & $12,64 \pm 0,11$ \\
\hline Д1 & $30,50 \pm 0,14$ & $18,54 \pm 0,13$ & $2,50 \pm 0,15$ & $16,04 \pm 0,12$ \\
\hline Д2 & $29,66 \pm 0,13$ & $17,84 \pm 0,16$ & $2,43 \pm 0,13$ & $15,41 \pm 0,12$ \\
\hline
\end{tabular}

$(\mathrm{n}=3, \mathrm{p}<0,05)$

Таблиця 8

Нітрогеновмісні сполуки бринзи на 20 добу визрівання (зрілий сир)

\begin{tabular}{|c|c|c|c|c|}
\hline $\begin{array}{c}\text { Зразки } \\
\text { бринзи }\end{array}$ & $\begin{array}{c}\text { Загальний } \\
\text { Нітроген, мг/г }\end{array}$ & $\begin{array}{c}\text { Загальний } \\
\text { розчинний } \\
\text { Нітроген, мг/г }\end{array}$ & $\begin{array}{c}\text { Нітроген небілкових розчинних } \\
\text { нітрогеновмісних сполук, мг/Г }\end{array}$ & $\begin{array}{c}\text { Нітроген розчинних } \\
\text { білкових речовин, мг/г }\end{array}$ \\
\hline $\mathrm{K}$ & $33,48 \pm 0,12$ & $28,50 \pm 0,13$ & $7,30 \pm 0,12$ & $21,2 \pm 0,12$ \\
\hline Д1 & $36,16 \pm 0,14$ & $30,02 \pm 0,13$ & $8,70 \pm 0,14$ & $21,32 \pm 0,14$ \\
\hline Д2 & $35,54 \pm 0,11$ & $29,28 \pm 0,11$ & $8,10 \pm 0,11$ & $21,18 \pm 0,1$ \\
\hline
\end{tabular}

$(n=3, p<0,05)$

Висновки. Визначено за органолептичними показниками максимально можливий відсоток заміни хлориду натрію хлоридом калію, який становить $30 \%$. Бринза, виготовлена із більшою часткою хлориду калію, набуває вади - гіркого смаку та йодистого присмаку.
Встановлено, що заміна 20 і $30 \%$ хлориду натрію хлоридом калію не здійснює негативного впливу на органолептичні та фізико-хімічні показники овечої бринзи. Вказані відсотки заміни кухонної солі хлоридом калію знижують масову частку $\mathrm{NaCl}$ на 0,70-0,97\% залежно від рівня заміни у бринзі.

\section{Список літератури:}

1. Петрович О. Мировой сыродел. Молочна промисловість. 2009. № 4(53). С. 14-17.

2. Какой сыр выгодно призводить в Украине? Молокопереробка. 2006. № 7. 
3. Каган Я.Р. Сыры с пробиотической микрофлорой. Сыроделие и маслоделие. 2009. № 2. С. 24-27.

4. Николаев А.М. Технология сыра. М. : Агропромиздат, 1985. 327 с.

5. Свириденко Ю.Я., Мордвинова В.А. Инновационные разработки в области сыроделия. Сыроделие и маслоделие. 2011. № 3. С. 17-19.

6. Генералова Б.А., Лобасенко Н.А., Шейфель О.А. и другие. Новый мягкий кислотно-сычужный сыр. Сыроделие. 2000. № 4. С. 14.

7. Скульська І.В., Цісарик О.Й. Вплив часткової заміни хлориду натрію на протеоліз при виробництві бринзи. Східно-Свропейський журнал передових технологій. 5/11 (71). 2014. С. 126.

8. ДСТУ 7065:2009. Бринза. Загальні технічні умови. Б3№ 10-2009/789. Видання офіційне. Київ : ДЕРЖСПОЖИВСТАНДАРТ України 2010. 12 с.

9. Ayyash M.M., Sherkat F., Shah N.P. The effect of $\mathrm{NaCl}$ substitution with $\mathrm{KCl}$ on Akawi cheese: Chemical composition, proteolysis, angiotensin-converting enzyme-inhibitory activity, probiotic survival, texture profile, and sensory properties. Journal of Dairy Science. 2012. Vol. 95, № 9. P. 4747-4759.

10. Lu Y., McMahon D.J. Effects of sodium chloride salting and substitution with potassium chloride on whey expulsion of Cheddar cheese. Journal of Dairy Science. 2015. Vol. 98, P. 78-88.

11. Urbach G. Contribution of lactic acid bacteria in flavour compound formation in dairy products. Int. Dairy J. 1995. Vol. 5. P. 877-903.

12. Скульская И.В., Цисарык О.И. Изменения белковых веществ брынзы под влиянием частичной замены поваренной соли хлоридом калия. Вестник Могилевского государственного университета продовольствия. 2016. № 1(20). С. 40-45.

\section{Skulska I.V., Tsisaryk O.I., Slyvka N.B. FORMATION OF QUALITATIVE INDICATORS OF THE CHEESE MADE AT PARTIAL REPLACEMENT OF SODIUM CHLORIDE}

The article examines the main organoleptic and physicochemical parameters of brine cheese, which is made from sheep's milk by advanced technology. The main technological solutions for ensuring the quality of cheese due to the possibility of improving some technological operations, namely salting operations by reducing the salt content in the cheese due to its partial replacement with potassium chloride. As a result of the conducted researches the maximum percentage of replacement of table salt by potassium chloride which makes $30 \%$ is established.

Samples of cheese with 50 and 100\% replacement were characterized by a bitter taste and iodine odor and aftertaste. Thus, the improvement of technology is 20 and $30 \%$ replacement of salt with potassium chloride. Due to this, the salt content is reduced to the minimum value provided by the current regulations $(4 \%)$. In the experimental samples, the salt content is generally $0.82-0.97 \%$ lower. This reduces the consumption of salt at the daily consumption of cheese $(70 \mathrm{~g})$. Thus, 3 samples of cheese were made with partial replacement of table salt with potassium chloride: $K$ - control sample using sodium chloride; D1 and D2 - cheese, made with 20 and $30 \%$ replacement of sodium chloride with potassium chloride, respectively.

According to the results of the research, the organoleptic and physicochemical parameters of the cheese, which is made by advanced technology, fully meet the requirements of regulatory documentation: the taste is moderately salty; the smell is pure, sour-milk, peculiar to sheep's milk; the consistency is elastic, brittle, but not brittle; color - white, slightly creamy; crust is missing. In the experimental samples of cheese there is an increase in dry matter content, which, accordingly, increases the yield of cheese. Since cheese contains a minimum salt content of 4\%, it is recommended to use it as a component of many dishes for people of different ages.

Key words: brine cheese, brynza, table salt (sodium chloride), potassium chloride, brine, bacterial preparation, pickling, ripening, storage. 